\title{
Are Other People's Books Difficult to Read? The Logic Books in Lewis Carroll's Private Library
}

\author{
Amirouche Moktefi \\ Ragnar Nurkse Department of Innovation and Governance, \\ Tallinn University of Technology \\ Akadeemia tee 3, \\ Tallinn 12618, Estonia \\ E-mail: amirouche.moktefi@ttu.ee
}

\begin{abstract}
It is well known that Charles L. Dodgson (alias Lewis Carroll, 18321898) worked on a logic treatise that would popularise the subject of symbolic logic. The first part appeared in 1896 but the next parts never appeared. It has been claimed that Carroll worked in isolation and did not read the main works of his time. The object of this paper is to inquire what Carroll's private library teaches us on his readings. The content of this library is known thanks to the sale catalogues that were issued when the library was auctioned at Carroll's death. This paper provides an overview of the logic books owned by Carroll. Then, it investigates the extent to which Carroll was acquainted with the main logic works of his time. Finally, the paper considers some methodological issues related to the use of 'library arguments' in intellectual history.
\end{abstract}

Keywords: history of logic, Lewis Carroll, library argument, private library

A Dutch proverb states that "Other people's books are difficult to read". Yet, reading others' work is an indispensable part of scientific activity. Hence, bibliographies, reading lists and library catalogues can provide valuable information for the historian of science. This study explores a case based on Lewis Carroll's (1832-1898) private library. Carroll (whose real name was Charles L. Dodgson) was a mathematical lecturer at Christ Church, University of Oxford (Wilson, 2008). In the last decade of his life, he actively worked on a treatise that would make symbolic logic accessible to a wide audience (Bartley, 1986; Moktefi, 2008; Abeles, 2010). A study of the logic books in Carroll's library is expected to evidence the extent to which he read the work of his contemporaries, especially the promoters of the new algebraic logic that developed in Victorian 
Britain (Grattan-Guinness, 2011). In this study, we first describe Carroll's library. Then, we inspect the sale catalogues to track the presence and dispersal of the logic books. Finally, we consider what the collection of logic books in Carroll's library teaches us on his logical work and acquaintances.

\section{The library}

At Carroll's death on 14 January 1898, his personal effects had to be quickly removed from his rooms at Christ Church, Oxford. Many of his belongings were dispersed or destroyed. In particular, the books he owned were offered for sale in an auction and were dispersed. Carroll's nephew and first biographer, Stuart D. Collingwood, recalled this episode with bitterness:

His library has now been broken up and, except for a few books retained by his nearest relatives, scattered to the winds; such dispersions are inevitable, but they are none the less regrettable. It always seems to me that one of the saddest things about the death of a literary man is the fact that the breakingup of his collection of books almost invariably follows; the building up of a good library, the work of a lifetime, has been so much labour lost, so far as future generations are concerned. Talent, yes, and genius too, are displayed not only in writing books but also in buying them, and it is a pity that the ruthless hammer of the auctioneer should render so much energy and skill fruitless. (Collingwood, 1898, pp. 135-136)

It seems that Carroll himself kept a register of his books but, unfortunately, it has not survived (Lovett, 2005, p. 8). The best source we have to reconstruct the content of his library is the sale catalogue of the auction that was organised on 10 May 1898. The auctioneer M. J. Brook organised the books in about a thousand lots that were only partly described in the catalogue. For instance, lot 585 was described as follows (Stern, 1997, p. 31):

585 Todhunter's History of the Theory of Probability, Tait's Quaternions, Halsted's Elements of Geometry and 6 others.

This entry provides sufficient information to identify three books in the lot but leaves six other items undescribed. Since lots evidently gathered books that belong to the same area (here, mathematics), it is reasonable to infer that the six items that were left undescribed were also mathematical volumes. Even the 
described items are not detailed as editions and dates of publication are seldom given. Also, many descriptions contain serious typos which suggest that the catalogue was dictated and hastily prepared for the auction.

Fortunately, several secondary sale catalogues have been issued by major booksellers who bought large amounts of books at the Brooks auction. Three such catalogues are of particular interest to our purpose. The first was issued by H. H. Blackwell in June 1898, one month after the auction, and contained about 360 volumes. Another catalogue was issued by J. Parker in October 1898 and described about 250 volumes. Finally, a catalogue was issued on 1898 by the Art and Antique Agency and contained more than 400 books. Interestingly, these secondary catalogues were prepared with more care and provide further information about the books than the primary catalogue prepared for the initial auction. In addition, they reveal new items that were left undescribed in the Brooks catalogue.

The primary and secondary catalogues have been first collected and reproduced by Stern in 1981 without an index (Stern, 1981). Then, in 1997, Stern provided an index of 2,231 titles that were found in the sale catalogues (Stern, 1997). More recently, Charlie Lovett prepared a catalogue of 2,365 titles that Carroll owned or read (Lovett, 2005). In addition to the books found in the library, Lovett included "any book which evidence indicates that Dodgson read, even if there is no evidence he owned a copy and even if we can only prove that he read part of it" (Lovett, 2005, p. 2). Carroll, evidently, owned many more books that are not found in any of these catalogues: prior to the auction, his family kept some books, offered some as gifts and sold some without record (Lovett, 2005, p. 3). Among the books left undescribed in the primary catalogue, many were not re-offered for sale and do not appear in secondary catalogues. It is also obvious that Carroll may have owned books that were not part of his library at his death. Although it is difficult to make a confident estimation of the total number of titles he owned in his library, it is safe to state that Carroll owned several thousand volumes, which make it a respectable private library for a Victorian intellectual of his status (Pearson, 2006). In addition to purchases, many books were gifts or presentation copies from their authors. Also, several volumes were books that Carroll used in his early school years or that previously belonged to his parents and were given to him.

The library apparently contained books for Carroll's use rather than for mere collection, but exceptions are certainly found. The content of the library evidences the variety of subjects that interested Carroll. It is with no surprise that we find 
large quantities of literary works but scientific books, especially medicine, are also well represented (Smith, 1984-1985). Further study of the content of the library should be carried out with great caution. If the presence of a title in the library reasonably indicates Carroll's knowledge of it, more investigation is needed to claim familiarity. One has notably to inquire the date of acquisition and the extent to which Carroll read or used that title. The absence of a title from the library should also be carefully considered. It should be first reminded that our incomplete knowledge of the contents of the library does not allow us to make definitive statements as to the absence of a given title from it. Then, one should not take the absence from the library as evidence of ignorance. For instance, Eric T. Bell stated that the presence of "mediocre" works by James Wood and Miles Bland in Carroll's library rather than George Peacock's was "indicative of [his] low mathematical taste and poor aptitude for mathematics" (Lennon, 1972, p. 407). But Carroll did actually refer to Peacock's algebra in the preface of his treatise on determinants (Dodgson, 1867, p. v). In line with Bell, it has often been stated that Carroll worked in isolation and "read comparatively little of the works of other mathematicians or logicians, preferring to develop his theories out of his own mind" (Hudson, 1976, p. 132). However, several recent historians argued that Carroll actually knew the main British mathematicians of his time: he met or corresponded with some of them, and referred to the work of others (Seneta, 1993, p. 182; Abeles, 1994, p. 16; 2010, p. 6; Wakeling, 2015, pp. 117-151).

It seems to some extent appropriate to claim that Carroll was not "what could be described as an active research mathematician. Indeed, he did not belong to any mathematical or scientific societies, nor did he subscribe to the major mathematics research journals of the day" (Rice \& Torrence, 2007, p. 93). However, one needs to keep in mind that Carroll was primarily a mathematics teacher, and most of his writings concerned educational issues. His library sale catalogues show that he owned copies of mathematical journals (such as the Messenger of Mathematics and the Quarterly Journal of Pure and Applied Mathematics) that were primarily aimed for teachers, students and junior mathematicians (Despeaux, 2007; Moktefi, 2007b, pp. 20-21).

Yet, it should not be inferred that Carroll worked in isolation. He actually cultivated a network of mathematical friends in Oxford with whom he regularly exchanged on various issues that occupied him. He also regularly appealed to the local professors, such as Henry J. S. Smith (mathematics) and John Cook Wilson (logic). Moreover, Carroll asked on several occasions for the opinion of 
his colleagues in Cambridge and beyond (Abeles, 1994; Wakeling, 2015). Even though he was not an avid and regular reader of the general mathematical literature of his time, Carroll certainly inquired on the advancement of the mathematical subjects that he specifically explored. The debate on the geometrical teaching that occurred in his time offers a good illustration of Carroll's effort to acquire and read the books that others wrote on a subject that was of high interest to him. Euclid's dominance was challenged by the late 1860s when several textbooks were offered to replace the Elements for teaching purposes (Moktefi, 2011). Carroll collected the main books that were offered as substitutes and reviewed them in Euclid and His Modern Rivals (Dodgson, 1879). Many of the books he discussed there are found in the sale catalogues of his library. It is the object of the next sections to inquire to what extent Carroll worked likewise in logic and to what extent he read the works of his time.

\section{The catalogues}

In the following, we refer to the existing catalogues and indexes with the letters attributed to them by Stern and Lovett as shown in Table 1:

Table 1. The list of catalogues and indexes

\begin{tabular}{|l|l|}
\hline Catalogue A & Issued by M. J. Brooks, 1898 \\
\hline Catalogue B & Issued by H. H. Blackwell, 1898 \\
\hline Catalogue D & Issued by J. Parker, 1898 \\
\hline Catalogue E & Issued by the Art and Antique Agency, 1898 \\
\hline Catalogue S & Issued by J. Stern, 1997 \\
\hline Catalogue L & Issued by Lovett, 2005 \\
\hline
\end{tabular}

In order to identify the logic books in Carroll's library, one faces an inevitable difficulty: to define the scope of logic. Indeed, especially in the nineteenth century, logic refers to a multitude of subjects and areas, including what would more likely find place today on the shelves of methodology, philosophy of science or philosophy of mind. For our purpose, we restricted the inquiry to works on deductive or formal logic because it was the area of logic that Carroll himself investigated. Hence, we excluded works on inductive logic and on chances. We also did not include several books in what was called mental philosophy and in religious thinking, even when 
they may be of interest to the logician. These restrictions explain the absence from our study of important works that Carroll actually owned, such as Dugald Stewart's Elements of the Philosophy of the Human Mind (whose first volume first appeared in 1792), William Whewell's Philosophy of the Inductive Sciences (first published in 1840), and John Venn's Logic of Chance (first published in 1866). Insofar as we are concerned with formal logic, there are eight lots in primary Catalogue $A$ that describe relevant titles (Stern, 1997, pp. 25-26):

505 Jevon's Principles of Sciences (2 vols.), Keyne's Formal Logic, Laws of Thought, and 4 others.

506 Picton’s Mystery of Matter, Minto's Logic, Man and his Dwelling Place and 8 others.

508 Bosanquet's Logic (2 vols.) De Morgan's Formal Logic, Kynes' Formal Logic and 3 others.

509 Sir Wm. Hamilton's Lectures (4vols.)

510 Mill's Logic (2 vols.), Mansel's Prolegomena, second edition, Mill's Examination of Hamilton, morocco, extra

515 Bradley's Principles of Logic, 8vo.

516 Newman's Grammar of Assent, Sidgwick's Falacies, Picture Logic and 8 others

517 Welton's Manual of Logic (2 vols.), Venn's Logic of Chance, Venn's Symbolic Logic and 4 others.

These 8 lots reveal 15 (deductive) logic titles, among which one appears twice (Keynes' Formal Logic in lots 505 and 508). All books can be easily identified as both author and title are given, except Picture Logic (in lot 516) and Laws of Thought (in lot 505). The former evidently is Swinburne's Picture Logic (first published in 1875). The latter most likely stands for either Boole's An Investigation of the Laws of Thought (published in 1854) or William Thomson's An Outline of the Necessary Laws of Thought (first published in 1849). Stern listed both Thomson and Boole in his index (Stern, 1997, pp. 115, 155), while Lovett included Thomson alone (Lovett, 2005, p. 314). In addition to the described volumes, the lots indicate the presence of additional items which are likely to be logic books but are left undescribed. 
Among the 15 titles found in catalogue $A, 10$ are also found in the secondary catalogues: 7 in catalogue $B$ and 3 in catalogue $D$. No title of catalogue $A$ is found in catalogue $E$. The titles described both in the primary catalogue and in one of the secondary catalogues give useful indication on the routes of dispersal of the volumes. Since the books were sold by lots, it is expected that all the books that were part of a given lot, including the undescribed items, will be found in the same secondary catalogue. Figure 1 condenses information gathered on the sale of the lots.

In addition to the 15 titles previously described in catalogue $A$, secondary catalogues reveal 8 titles that were not previously described: 2 are revealed in catalogue $B$ (Studies in Logic by the Members of Johns Hopkins University, and Richard Whately's Logic), 3 are revealed in catalogue D (Augustus De Morgan's Proposed System of Logic, James William Gilbart's Logic for the Million, and Rudolph H. Lotze's Logic), and finally 3 are revealed in catalogue $E$ (Henry Holman's Questions on Logic, J. P. Hughlings' The Logic of Names, and W. Stanley Jevons' Pure Logic). These titles, evidently, were among the undescribed items mentioned in the lots of catalogue $A$, likely one of the lots identified above, but possibly in some other unidentified lots. To determine the provenance of these new titles, one has to keep in mind that the books revealed in a given secondary catalogue could not have been part of a lot which is known to have been bought by another purchaser. For instance, the three books revealed by catalogue $D$ evidently were not part of the lots $(509,510$, and 517) which were sold to the bookseller who issued catalogue $B$. They might well correspond to the three items left undescribed in lot 508, which is known to have been purchased by the bookseller who issued catalogue $D$.

This method of profiling can give valuable information about undecided items. For instance, it has been stated that Stern and Lovett disagreed as to the identification of the Laws of Thought volume described in lot 505. Stern attributed it to Boole, while Lovett favoured Thomson. The latter's has the advantage of being described in secondary catalogue $B$, while Boole's never appears in subsequent catalogues. Tracking the disputed volume after the sale may help in determining the authorship. First, it has been seen that Keynes' Formal Logic appeared twice in primary catalogue $A$ (in lots 505 and 508), but only once in secondary catalogues (in $D$ ). Since lot 508 was purchased by the bookseller who issued catalogue $D$, it follows that the copy of Keynes found in catalogue $D$ likely came from that lot. Hence, the copy of Keynes from lot 505 was apparently not re-offered for sale. Jevons' volume from the same lot 505 also 

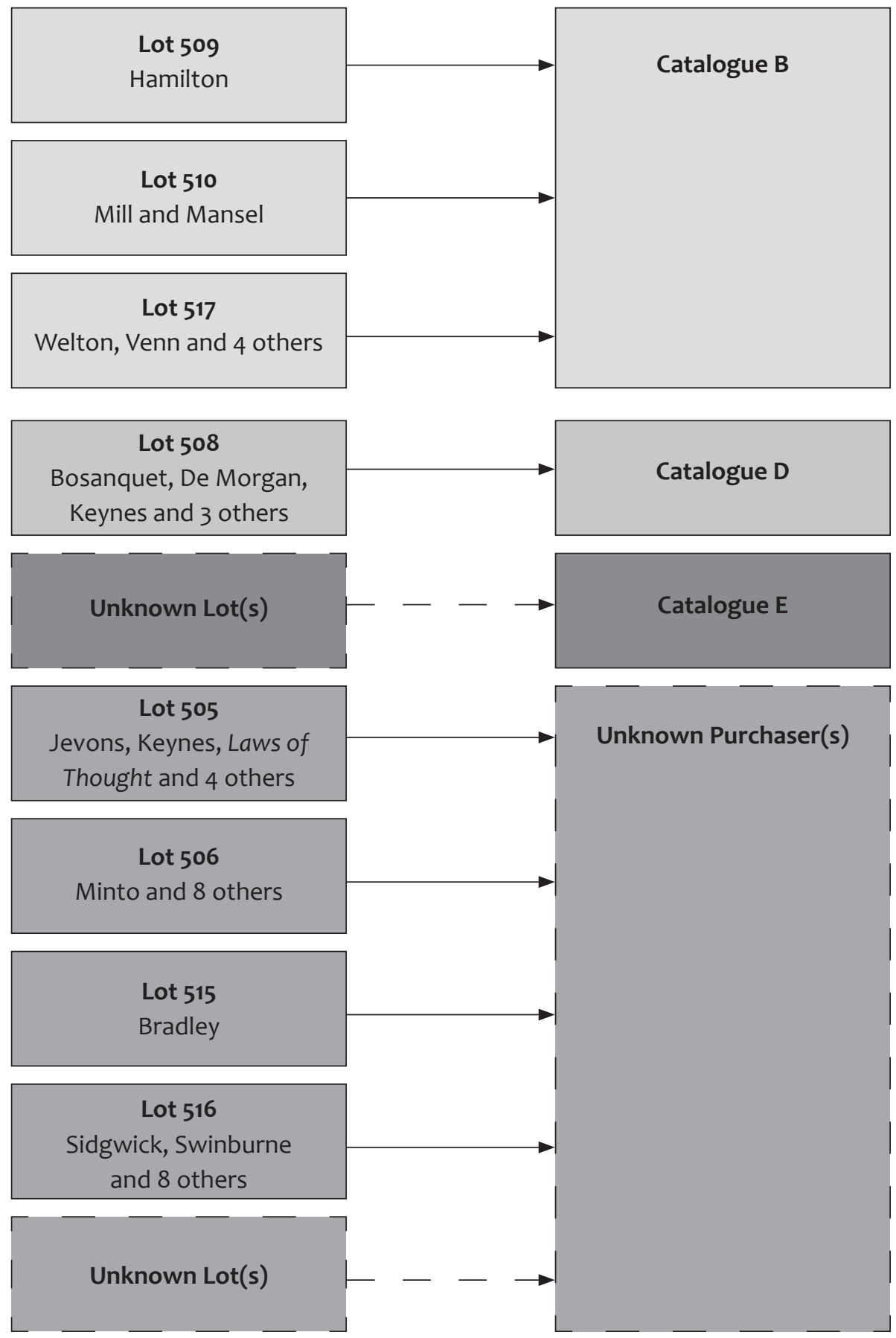

Figure 1. The dispersal of logic books 
is not found in any secondary catalogue. It follows that lot 505 likely was not sold to any of the three major booksellers who issued catalogues $B, D$, and $E$. But Thomson's Laws of Thought was found in catalogue B. So, the presence of Thomson ironically suggests that it was not the disputed title described as Laws of Thought in lot 505 of Catalogue $A$. This argument based on the sale catalogues rather supports Boole as the most likely candidate.

In addition to the 23 titles revealed in catalogues $A, B, D$ and $E$, further titles have been added by Stern and Lovett. Stern included the disputed Boole as stated above. Lovett added two titles: Thomas Fowler's Elements of Deductive Logic and John Huyshe's A Treatise on Logic. However, he held both to be "uncertain" because their identification was questionable. Finally, we can safely add William Renton's Analytic Theory of Logic (published in 1887) to the contents of Carroll's library, even though one cannot tell if it was there at Carroll's death. Indeed, a letter dated 6 September 1888 from Renton to Carroll reveals that the former sent a copy of his book to the latter (Weaver, 1980, p. 154). These various sources provide appropriate information to compile a list of logic titles that were present in Carroll's library, as shown in Table 2:

Table 2. The logic titles revealed in the catalogues

\begin{tabular}{|l|l|}
\hline Titles revealed in Catalogue A & 15 \\
\hline Titles revealed in Catalogue B & 2 \\
\hline Titles revealed in Catalogue D & 3 \\
\hline Titles revealed in Catalogue E & 3 \\
\hline Titles revealed in Catalogue S & 1 \\
\hline Titles revealed in Catalogue L & 2 \\
\hline Titles not found in above catalogues & 1 \\
\hline Total & 27 \\
\hline
\end{tabular}

Hence, we have a list of 27 titles identified in Carroll's library, among which 3 are uncertain. This list is appended to this note. It is hoped that other titles will appear in sale catalogues, descriptions of private collections or in other sources. 


\section{The logic books}

A first look at the list of logic books in Carroll's library shows that he owned much of what one would expect a British logician of the time to read. It is true that a modern reader will immediately notice the absence of Gottlob Frege's Begriffsschrifft (published in 1879), commonly considered as one of the most important books in the history of logic. But one can hardly blame Carroll for not owning it, if he did not, for this book did not get recognition before the beginning of the twentieth century. In Britain, and especially in Oxford, a student of logic would rather read other classical texts. A guide-book for Oxford students from 1861 recommends a thorough knowledge of Aldrich's compendium:

The Oxford system has always, in accordance with the plan pursued in its other branches of study, required a thorough knowledge of a certain textbook as a foundation for Logic. This text-book, the shorter Compendium of Aldrich, is indeed miserably deficient, even when read (as it must be by the Class-man) in Professor Mansel's edition with notes and appendix. It is a compendium of a compendium, the meager fare on which Oxford had been content to subsist till Archbishop Whately and Sir William Hamilton recovered for the study some portion of its ancient consideration; but until something better is provided to take its place, it must be got up, a great deal of it by heart, and the rest with the greatest care. (Burrows, 1861, p. 82)

Mansel, Hamilton and Whately are all found in Carroll's library, as is found Mill's System of Logic (first published in 1843, Carroll's copy was of the 1851 edition). Carroll likely was familiar with these texts since his early years in Oxford. On 13 March 1855, he recorded in his journal a reading plan where Mill's logic is listed (Wakeling, 1993, p. 74).

Evidently, Carroll was also familiar with De Morgan's logic works. De Morgan has been a lifelong companion to Carroll's mathematical investigations. In addition to the first editions of Formal Logic (1847) and Syllabus of a Proposed System of Logic (1860), Carroll's library contained six other works by De Morgan on various mathematical subjects. One of them, An Essay on Probabilities (first published in 1838) was apparently bought by Carroll on 23 February 1858 (Wakeling, 1995, p. 158). Later, Carroll appended to his defence of Euclid large passages from a text by De Morgan with whom he shared admiration for Euclid (Dodgson, 1879, pp. 221-226). Finally, Carroll referred to several problems by De Morgan in the projected second part of his Symbolic Logic (Bartley, 1986, 
p. 477). De Morgan can be seen as a major contributor to both traditional and symbolic logic, both directions being well represented in Carroll's library.

Indeed, one finds several traditional logic textbooks and treatises among Carroll's books. Some of them are the work of Oxford logicians with whom Carroll regularly exchanged: William Thomson, Thomas Fowler, Bernard Bosanquet and Francis H. Bradley. Others were minor texts that enjoyed some success in Carroll's time by William Minto, Alfred Sidgwick and James Welton (with whom Carroll exchanged some correspondence in 1894). Finally, one might include in this tradition Keynes' essential work: Studies and Exercises in Formal Logic (first published in 1884, with subsequent editions in 1887, 1894 and 1906). This work was viewed as the culmination of non-mathematical formal logic in its time. Carroll owned at least two copies of it, including a copy of the third edition inscribed "Rev. C. L. Dodgson, with the Author's kind regards" (Stern, 1997, p. 67). He referred to both copies in his journal (Wakeling, 2005, pp. 152, 180) and in his Symbolic Logic (Bartley, 1986, pp. 235, 478).

Two minor logic works from Carroll's library deserve a special notice: Gilbart's Logic for the Million (first published in 1851, Carroll's copy from the 1865 edition) and Swinburne's Picture Logic (first published in 1875). Indeed, both were books that aimed at popularising logic and, as such, seem to contradict Carroll's claim that his Symbolic Logic was "the very first attempt (with the exception of [his] own little book, The Game of Logic, published in 1886, a very incomplete performance) that has been made to popularise this fascinating subject" (Carroll, 1897, p. xiv). Carroll's ownership of Gilbart and Swinburne's popular books suggests that it was symbolic logic specifically that Carroll had in mind when he claimed priority for the popularisation of this 'fascinating subject' (Moktefi, 2015).

The last set of books that will be described assembles the works that were developed within the symbolic tradition that originated in Boole and was subsequently pursued in Britain by Jevons and Venn. All three authors are found in the library. Even though it is uncertain, Carroll likely owned a copy of Boole's Laws of Thought (1854). However, it is undisputed that Carroll knew Boole's logical work, either from the latter's writings or through other sources. On 25 May 1876, he reported in his journal using a notation after "Boole's plan but with an addition which occurred to [him] the other day" (Wakeling, 2001, pp. 463-464). On 20 November 1884, he recorded "getting to a simpler notation than Boole's" (Wakeling, 2004, p. 153). Finally, Carroll also referred to Boole's Laws of Thought in his projected Symbolic Logic where he devoted 
a chapter to the solution of problems set by other writers (Bartley, 1986, pp. 477-478). In addition to De Morgan, Keynes and Boole, Carroll also cites W. B. Grove, Jevons, Venn and the Members of Johns Hopkins University.

It is unclear when and to what extent Carroll discovered Venn's logic work. There are certainly many resemblances between their works, notably the title of their books and the invention of original diagrams. But there is no direct reference to Venn in Carroll's writings prior to 1894 . That year, Carroll spread among logicians a problem known as the barbershop paradox to collect their opinion (Carroll, 1894; Moktefi, 2007a). Interestingly, Carroll first contacted Henry Sidgwick, Professor of Philosophy at the University of Cambridge, and asked him "who is the chief Logician in your University?" (Dodgson, 1894). It is likely that it was through Sidgwick that Carroll was introduced to Venn. In the second edition of his Symbolic Logic published that year (1894), Venn addressed the barbershop problem and renamed it the "Alice problem" because "the proposer is, to the general reader, better known in a very different branch of literature" (Venn, 1894, p. 442). Carroll later referred in his own Symbolic Logic to both editions of Venn's (Carroll, 1897, p. 175; Bartley, 1986, p. 478).

Even though Carroll and Venn might not have got in contact prior to 1894, it is evident that they knew of each other earlier. Indeed, Venn reacted in 1887 to a review of Carroll's Game of Logic because he was unhappy with the reviewer's claim that Carroll's scheme handles particular propositions better than Venn's (Venn, 1887; Moktefi \& Pietarinen, 2015). Also, Carroll is known to have worked in 1890 on a logic problem about "shareholders and bondholders" that was first published by Venn in 1876 (Abeles, 2010, p. 16). However, Carroll might have discovered it in other sources as logic problems circulated among the logicians of the time. Venn's problem is notably found in the collection of Studies in Logic (Peirce, 1883, pp. 51-52) that Carroll already knew in 1890. Indeed, his logic notebook preserved at Princeton University shows that he was working that year on logic problems from Jevons' Principles of Science and the volume of Studies in Logic that gathered essays by Charles S. Peirce and his students. Both titles are found in Carroll's library and are cited by Carroll in his chapter, alluded to earlier, of problems set by other writers (Bartley, 1986, p. 478).

There are some important omissions from Carroll's library, insofar as it has been possible to reconstruct it. Among British symbolic logicians, the only notable omission seems to be Alexander Macfarlane's Principles of the Algebra of Logic (published in 1879), although one cannot tell for sure whether it was absent from the library. Naturally, Hugh MacColl and William E. Johnson are also 
absent since they did not publish logic books in Carroll's lifetime. Although both were contemporaries of Carroll and exposed their logical theories in articles, they only published their treatises in their late years, MacColl in 1906 and Johnson in three volumes in 1921, 1922, and 1924. It is interesting to note that both logicians addressed Carroll's barbershop problem in their writings. In addition, MacColl certainly was familiar with Carroll's Symbolic Logic as he reviewed the book for the Athenaeum (MacColl, 1896; Abeles \& Moktefi, 2011). A more severe omission from Carroll's library, if confirmed, would be Ernest Schröder. However, this would hardly be a surprise as Carroll's intellectual life seems to have been essentially centred on the British scene. In particular, several instances in his writings attest to his defiance of ideas from the Continent, especially from Germany. There are also few noteworthy traditional logic works that are absent. The most notable is Alexander Bain's Logic (first published in 1870). But one might also mention E. E. Constance Jones' works published in the 1890s.

It has been previously argued that absence from the library should not be confused with ignorance. John Cook Wilson, the Wykeham Professor of Logic at the University of Oxford, offers a good illustration of this principle. It is true that Cook Wilson did not publish a logic treatise in his lifetime. His logic papers were posthumously edited and published by A. S. L. Farquharson (Cook Wilson, 1926). But Cook Wilson already published several titles in Carroll's time, notably a lecture On an Evolutionist Theory of Axioms in 1889 that would have highly interested Carroll. That none of Cook Wilson's works is found in the sale catalogues of Carroll's library certainly should not be interpreted as evidence of ignorance. Indeed, Carroll and Cook Wilson already knew each other in the mid-1880s and continued to regularly exchange on various subjects in geometry, chances and logic until Carroll's death (Marion \& Moktefi, 2014). In particular, the two men engaged in the period 1892-1894 in a long dispute on the nature of hypotheticals which led to the publication of the barbershop paradox alluded to earlier. It is actually reasonable to claim that Cook Wilson was the logician with whom Carroll was the most familiar, and yet, he seems absent from his library. In contrast, Carroll owned three books by Venn, and yet, it is unclear the extent to which he was familiar with him. This example demonstrates the caution that is necessary to interpret the contents of a library and what lessons it teaches us on its owner. 


\section{Conclusion}

This study shows that Carroll owned the main logic books that circulated in Britain at that period. In particular, he clearly had access to most of the symbolic logic books that were published in the English-speaking world. Like most of his British contemporaries, he seems to have paid little attention to the works that were developing on the Continent. It is more difficult to state to what extent Carroll was familiar with the books he owned, especially as he seldom refers to them in the exposition of his logic theory. It is true that Carroll wrote his treatise as to be accessible to a large audience and might thus have intentionally avoided exegesis and critical discussions, even omitting to include a definition of logic. However, Carroll's private writings, notably his journal, also lack reference to other authors. Although many elements of Carroll's logic are found in earlier authors, they are introduced in his journal as discoveries of his own. Another difficulty to assess Carroll's familiarity with the achievements of symbolic logic in his time is that much of it was published in journals which are not found in his library. Even for the authors he mentions, Carroll mainly referred to problems they set rather than to their methods of solution. An exception to this remark is his discussion of Euler's and Venn's diagrammatic methods which he described in order to demonstrate the superiority of his own method (Carroll, 1897, pp. 173-183).

Symbolic logicians in the nineteenth century certainly compared their notations and tackled similar problems to exhibit the power of their methods (DurandRichard \& Moktefi, 2014). In this respect, Carroll unquestionably belonged to that rising community. In particular, he was convinced that symbolic methods of solution were superior and will ultimately supersede traditional methods, as he explained it to his publisher Macmillan in a letter dated on 19 October 1895:

I have no doubt that Symbolic Logic (not necessarily my particular method, but some such method) will, some day, supersede Formal Logic, as it is immensely superior to it: but there are no signs, as yet, of such a revolution. (Cohen \& Gandolfo, 1987, p. 323)

Carroll was conscious that important changes were happening in the realm of logic, even though symbolic logic did not acquire yet the recognition he believed it to deserve. He entered the competition with his own symbolic method but apparently did not try to get in touch with other opponents, especially outside Britain. As such, he was peripheral to, if not outside, the formidable network 
that was growing in Europe and North America, with many logicians exchanging rich correspondence and discussing each other's work privately and in print (Peckhaus, 1998). This agitation culminated at the Philosophy Congress in Paris in 1900 that gathered the main symbolic logicians for the first time. Carroll remained loyal to his immediate network made of Oxonian friends and family members to whom he sent his logic problems. The controversy that turned on the barbershop problem probably was his moment of fame that introduced him to most of his contemporary logicians in Britain but he went fast forgotten shortly after his death. He probably would have remained ignored as a logician if he did not happen to be the author of the wonderful Alice tales and did not publish in 1895 a short note: "What the Tortoise said to Achilles" that intrigued logicians ever since (Carroll, 1895; Moktefi \& Abeles, 2016).

It might be tempting at first to compare the logic holdings of Carroll's library with other collections of logic books from the same period. For instance, Venn donated an impressive collection of more than a thousand logic volumes to Cambridge University Library in 1888 (Francis, 1889; Boswell, 1995). It would be misleading to compare these two collections without keeping in mind that Carroll and Venn evidently had different collecting practices. The former gathered few books that were accessible and relevant to him in relation to his immediate study of logic while the latter aimed at the formation of a special collection that would gather any work of logic that was ever known to exist. It follows that Carroll's library is more informative on the logic literature that circulated in late Victorian Britain. Interestingly, Venn did not include in his donation many of the symbolic logic books that he owned and which he probably continued to use for the purpose of his study. In a way, a catalogue of the books that Venn did not donate would certainly give a better picture of his interests than the collection of books he included in his donation. Not all symbolic logicians could afford to collect logic books. Hugh MacColl certainly had a different logic library, as he explained in a letter to Bradley, dated on 14 December 1904:

If I were a professor of logic, I would certainly get your books and study them; but as I am only an amateur, driven by I know not what mental perversity towards abstract studies from which I can never hope to reap any material gain or benefit, I am afraid I must content myself with the few books on logic that I already possess [...] I cannot afford the luxury of a large library. (Keene, 1999, p. 308)

When we study private libraries, it is important to keep in mind the variety of motivations, resources and practices that move their owners (Potten, 2015). 
Hence, claims related to the presence or absence of a given book in an author's library should take into account these individual conducts as well as the social and cultural practices of the community that is considered. These methodological imperatives and the confrontation with other sources are necessary to secure library arguments. Although exceptions exist (Harvey, 1980; Anellis, 1994; Brobjer, 1997; Zurlini, 2004; Leu, Keller \& Weidmann, 2008), one seldom meets with library studies in intellectual history literature. It is hoped that the present study will contribute to overcome this prejudice as libraries certainly offer valuable information on their owners.

\section{Acknowledgments}

This work uses material that was accessed thanks to research grants from the Maison Française d'Oxford (2006) and the Friends of the University of Princeton Library (2007). Also, this paper draws upon research support from the ERC project 'Abduction in the age of uncertainty' (PUT 1305, Principal Investigator: Prof. Ahti-Veikko Pietarinen).

\section{Appendix}

This is an alphabetical list of the 27 (formal) logic books known or assumed to have been owned by Lewis Carroll in his private library. As explained in the article, it is mainly based on the sale catalogues $A, B, D, E$, and indexes $S$ and $L$. We added one title that is not found in any of these sources. For each title, we provided information gathered from the catalogues but, when possible, we added bibliographical information to make each reference more complete. Each title is followed \{between braces\} by the catalogue(s) where it is listed and its number in each catalogue. Catalogue $D$ being originally unnumbered, we followed Lovett's numbering. It is hoped that further titles will be revealed in future auctions and studies.

[1] Boole, G., An Investigation of the Laws of Thought, on which are Founded the Mathematical Theories of Logic and Probabilities, London: Macmillan and Co., 1854. \{Uncertain; possibly $A-505, S-532\}$ 
[2] Bosanquet, B., Logic, or the Morphology of Knowledge, 2 vols., Oxford: Clarendon Press, 1888. $\{A-508, D-105, S-536, L-199\}$

[3] Bradley, F. H., The Principles of Logic, London: Kegan Paul, Trench, \& Co., $1883\{A-515, S-557, L-228\}$

[4] De Morgan, A., Formal Logic: or, the Calculus of Inference, Necessary and Probable, London: Taylor \& Walton, 1847. $\{A-508, D-52, S-814, L-557\}$

[5] De Morgan, A., Syllabus of a Proposed System of Logic, London: Walton \& Maberly, 1860. [D-106, S-817, L-558]

[6] Fowler, T., Elements of Deductive Logic: Designed Mainly for the Use of Junior Students in the Universities, $2^{\text {nd }}$ ed., Oxford: Clarendon press, 1867. \{Uncertain; $L-726\}$

[7] Gilbart, J. W., Logic for the Million; A Familiar Exposition of the Art of Reasoning; With an Appendix on the Philosophy of Language, London: Bell \& Daldy, 1865. $\{D-107, S-1064, L-772\}$

[8] Hamilton, Sir W., Lectures on Metaphysics and Logic, edited by H. L. Mansel $\& \mathrm{~J}$. Veitch, 4 vols., $2^{\text {nd }}$ ed., Edinburgh \& London: William Blackwood and Sons, $1861\{A-509, B-1065, S-1132, L-858\}$

[9] Holman, H., Questions on Logic: Part I., London: W. B. Clive \& Co., 1891. $\{E-247, S-1214, L-953\}$

[10] Hughlings, I. P., The Logic of Names: An Introduction to Boole's Laws of Thought, London: James Walton, 1869. \{E-235, S-1269, L-1020\}

[11] Huyshe, J., A Treatise on Logic, on the Basis of Aldrich, with illustrative notes, $3^{\text {rd }}$ ed., Oxford: J. Vincent, 1842. \{Uncertain; $\left.L-1029\right\}$

[12] Jevons, W. S., The Principles of Science: a Treatise on Logic and Scientific Method, 2 vols., London: Macmillan and Co., [Probably 1 ${ }^{\text {st }}$ ed., 1874]. $\{A-505$, $S-1307, L-1074\}$

[13] Jevons, W. S., Pure logic, or, the Logic of Quality apart from Quantity: with Remarks on Boole's System, and on the Relation of Logic and Mathematics, London: Edward Stanford, 1864. \{E-401, S-1308, L-1075\}

[14] Keynes, J. N., Studies and Exercises in Formal Logic: Including a Generalization of Logical Processes in their Application to Complex Inferences, London: Macmillan 
and Co, 2 copies: $3^{\text {rd }}$ ed., 1894 [and probably $2^{\text {nd }}$ ed., 1887]. $\{A-505 \& A-508$, $D-108, S-1351, L-1127\}$

[15] Lotze, R. H., Logic: in Three Books, of Thought, of Investigation, and of Knowledge, English translation by B. Bosanquet, Oxford: Clarendon press, 1884. $\{D-109, S-1444, L-1254\}$

[16] Mansel, H. L., Prolegomena Logica: An Inquiry into the Psychological Character of Logical Processes, $2^{\text {nd }}$ ed., Oxford: Henry Hammans \& London: Whittaker, 1860. $\{A-510, B-1133, S-1482, L-1296\}$

[17] Mill, J. S., An Examination of Sir William Hamilton's Philosophy, and of the Principal Philosophical Questions Discussed in his Writings, $4^{\text {th }}$ ed., London: Longmans, Green, Reader and Dyer, 1872. $\{A-510, B-1139, S-1518, L-1349\}$

[18] Mill, J. S., A System of Logic, Ratiocinative and Inductive, Being a Connected View of the Principles of Evidence, and the Methods of Scientific Investigation, 2 vols., $3^{\text {rd }}$ ed., London: John W. Parker, 1851. $\{A-510, B-1140, S-1519, L-1350\}$

[19] Minto, W., Logic: Inductive and Deductive, London: John Murray, [1893 or 1894]. $\{A-506, S-1529, L-1364\}$

[20] Members of the Johns Hopkins University, Studies in Logic, Boston: Little Brown and Co., 1883. \{B-1245, S-154, L-1518\}

[21] Renton, W., Analytic Theory of Logic, Edinburgh: James Thin \& London: Simpkin, Marshall \& Co, 1887 \{not previously listed\}

[22] Sigdwick, A., Fallacies: A view of Logic from the Practical Side, London: Kegan Paul, Trench, \& Co. [edition unknown, $1^{\text {st }}$ ed. in 1883]. \{A-516, S-1885, $L-1845\}$

[23] Swinburne, A. J., Picture Logic; or, the Grave Made Gay: An Attempt to Popularise the Science of Reasoning by the Combination of Humorous Pictures with Examples of Reasoning Taken from Daily Life, London: Longmans, Green, and Co., [edition unknown, $1^{\text {st }}$ ed. in 1875]. $\{A-516, S-71, L-1985\}$

[24] Thomson, W., An Outline of the Necessary Laws of Thought: A Treatise on Pure and Applied Logic, $2^{\text {nd }}$ ed., London: William Pickering \& Oxford: W. Graham, 1849. \{Possibly $A-505, B-1257, S-2069, L-2076\}$

[25] Venn, J., Symbolic logic, London: Macmillan \& Co, $2^{\text {nd }}$ ed., 1894. $\{A-517$, $B-1273, S-2121$ a, $L-2154\}$ 
[26] Welton, J., A Manual of Logic, 2 vols., London: W. B. Clive, vol. 1: 1891, vol. 2: 1896. $\{A-517, B-1286 \& B-1287, S-2175, L-2227\}$

[27] Whately, R., Logic [From the Encyclopaedia Metropolitana], $2^{\text {nd }}$ ed., London: J. J. Griffin \& Glasgow: R. Griffin, 1849. \{B-1289, S-2178, L-2231\}

\section{References}

Abeles, F. F. (1994), The Mathematical Pamphlets of Charles Lutwidge Dodgson and Related Pieces, New York: the Lewis Carroll Society of North America.

- (2010), The Logic Pamphlets of Charles Lutwidge Dodgson and Related Pieces, New York: The Lewis Carroll Society of North America.

Abeles, F. F. \& Moktefi, A. (2011), 'Hugh MacColl and Lewis Carroll: crosscurrents in geometry and logic,' Philosophia Scientiae, vol. 15, no. 1, pp. 55-76.

https://doi.org/10.4000/philosophiascientiae.362

Anellis, I. H. (1994), 'Logic and mathematics in the library of Casimir Lewy', Modern Logic, vol. 4, no. 3, pp. 286-298.

Bartley III, W. W. (1986), Lewis Carroll's Symbolic Logic, $2^{\text {nd }}$ ed., New York: C. N. Potter.

Boswell, T. (1995), 'A note on John Venn as a collector and bibliographer of works on logic,' History and Philosophy of Logic, vol. 16, no. 1, pp. 121-125. https://doi.org/10.1080/01445349508837244

Brobjer, T. H. (1997), "Nietzsche's reading and private library, 1885-1889," Journal of the History of Ideas, vol. 58, no. 4, pp. 663-693.

https://doi.org/10.1353/jhi.1997.0034

Burrows, M. (1861), Pass and Class: An Oxford Guide-Book, Oxford \& London: J. H. and J. Parker.

Carroll, L. (1894), 'A logical paradox,' Mind, vol. 3, no. 11, pp. 436-438. https://doi.org/10.1093/mind/IV.14.278

_ (1895), 'What the Tortoise said to Achilles,' Mind, vol. 4, no. 14, pp. 278-280. (1897), Symbolic Logic. Part 1: Elementary, $4^{\text {th }}$ ed., London: Macmillan.

Cohen, M. N. \& Gandolfo, A. (1987), Lewis Carroll and the House of Macmillan, Cambridge: Cambridge University Press.

Collingwood, S. D. (1898), The Life and Letters of Lewis Carroll (rev. C. L. Dodgson), London: T. Fisher Unwin.

Cook Wilson, J. (1926), Statement and Inference: with Other Philosophical Papers, 2 vols., edited by A. S. L. Farquharson, Oxford: Clarendon Press. 
Despeaux, S. E. (2007), 'Launching mathematical research without a formal mandate: The role of university-affiliated journals in Britain, 1837-1870,' Historia Mathematica, vol. 34, pp. 89-106. https://doi.org/10.1016/j.hm.2006.02.005

Dodgson, C. L. (1867), Elementary Treatise on Determinants, London: Macmillan. (1879), Euclid and his Modern Rivals, London: Macmillan. (1894), 'Letter to Henry Sidgwick, 13 March 1894,' The Henry Sidgwick Papers, Trinity College Library, Cambridge, UK, add. Ms. c. 93. 106.

Durand-Richard, M.-J. \& Moktefi, A. (2014), 'Algèbre et logique symboliques: arbitraire du signe et langage formel,' in J.-Y. Béziau (ed.) La Pointure du Symbole, Paris: Pétra, pp. 295-328.

Francis, H. T. (1889), Catalogue of a Collection of Books on Logic Presented to the Library by John Venn, Cambridge: University Press.

Grattan-Guinness, I. (2011), 'Victorian logic: From Whately to Russell,' in R. Flood, A. Rice \& R. Wilson (eds.) Mathematics in Victorian Britain, Oxford: Oxford University Press, pp. 359-374.

Harvey, R. A. (1980), 'The private library of Henry Cavendish (1731-1810), The Library, no. 2, pp. 281-292. https://doi.org/10.1093/library/s6-II.3.281

Hudson, D. (1976), Lewis Carroll: An Illustrated Biography, $2^{\text {nd }}$ ed., London: Constable.

Keene, C. A. (1999), F. H. Bradley. Selected Correspondence: June 1872 -December 1904, Bristol: Thoemmes.

Lennon F. B. (1972), The Life of Lewis Carroll, New York: Dover.

Leu, U. B.; Keller, R. \& Weidmann, S. (2008), Conrad Gessner's Private Library, Leiden \& Boston: Brill. https://doi.org/10.1163/ej.9789004167230.i-311

Lovett, C. (2005), Lewis Carroll among his Books: A Descriptive Catalogue of the Private Library of Charles L. Dodgson, Jefferson, North Carolina \& London: McFarland.

MacColl, H. (1896), "Review of Lewis Carroll's Symbolic Logic: Part I," The Athenaeum, no. 3599, 17 October, pp. 520-521.

Marion, M. \& Moktefi, A. (2014), 'La logique symbolique en débat à Oxford à la fin du XIX ${ }^{\mathrm{e}}$ siècle: les disputes logiques de Lewis Carroll et John Cook Wilson,' Revue d'Histoire des Sciences, vol. 67, no. 2, pp. 185-205. https://doi.org/10.3917/rhs.672.0185

Moktefi, A. (2007a), 'Lewis Carroll and the British nineteenth-century logicians on the barber shop problem,' Proceedings of The Canadian Society for the History and Philosophy of Mathematics, vol. 20, pp. 189-199.

(2007b), Déduire et Séduire: La Logique Symbolique de Lewis Carroll, PhD dissertation, Strasbourg: Université Louis Pasteur.

- (2008), "Lewis Carroll's Logic," in D. M. Gabbay \& J. Woods (eds.) British Logic in the Nineteenth Century, Handbook of the History of logic series, vol. 4, Amsterdam: North-Holland, pp. 457-505. https://doi.org/10.1016/S1874-5857(08)80013-1 
(2011), 'Geometry: the Euclid debate,' in R. Flood, A. Rice \& R. Wilson (eds.) Mathematics in Victorian Britain, Oxford: Oxford University Press, pp. 320-336.

(2015), "On the social utility of symbolic logic: Lewis Carroll against 'The Logicians'," Studia Metodologiczne, vol. 35, pp. 133-150.

Moktefi A. \& Abeles F. F. (2016), “The making of 'What the Tortoise said to Achilles': Lewis Carroll's logical investigations toward a workable theory of hypotheticals," The Carrollian: The Lewis Carroll Journal, vol. 28, pp. 14-47.

Moktefi, A. \& Pietarinen, A.-V. (2015), 'On the diagrammatic representation of existential statements with Venn diagrams,' Journal of Logic, Language and Information, vol. 24, no. 4 (December), pp. 361-374. https://doi.org/10.1007/s10849-015-9228-1

Pearson, D. (2006), 'Private libraries and the collecting instinct,' in A. Black \& P. Hoare (eds.) The Cambridge History of Libraries in Britain and Ireland, vol. 3, Cambridge: Cambridge University Press, pp. 180-202. https://doi.org/10.1017/CHOL9780521780971.016

Peckhaus, V. (1998), 'Hugh MacColl and the German algebra of logic,' Nordic Journal of Philosophical Logic, vol. 3, pp. 17-34.

Peirce, C. S. (1883), Studies in Logic, Boston: Little, Brown, and Company.

Potten, E. (2015), 'Beyond bibliophilia: contextualizing private libraries in the nineteenth century,' Library \& Information History, vol. 31, no. 2, pp. 73-94. https://doi.org/10.1179/1758348914Z.00000000076

Rice, A. \& Torrence, E. (2007), “'Shutting up like a telescope': Lewis Carroll's 'curious' condensation of method for evaluating determinants," The College Mathematics Journal, vol. 38, no. 2, pp. 85-95.

Seneta, E. (1993), “Lewis Carroll's 'Pillow Problems': on the 1993 centenary," Statistical Science, vol. 8, no. 2, pp. 180-186. https://doi.org/10.1214/ss/1177011011

Smith, W. J. (1984-1985), “Dodgson's scientific interests with reference to the books in his library," Jabberwocky, no. 61, pp. 3-9.

Stern, J. (1981), Lewis Carroll's Library, New York: The Lewis Carroll Society of North America.

(1997), Lewis Carroll Bibliophile, Luton, Bedfordshire: White Stone publishing.

Venn, J. (1887), 'The game of logic,' Nature, vol. 36, no. 916 (19 May), pp. 53-54. https://doi.org/10.1038/036053g0

(1894), Symbolic Logic, $2^{\text {nd }}$ ed., London: Macmillan.

Wakeling, E. (1993-2007), Lewis Carroll's Diaries: The Private Journals of Charles Lutwidge Dodgson (Lewis Carroll), 10 vols., Luton, Beds \& Clifford, Herefordshire: The Lewis Carroll Society (vol. 1, 1993; vol. 3, 1995; vol. 6, 2001; vol. 8, 2004; vol. 9, 2005).

- (2015), Lewis Carroll: The Man and his Circle, London \& New York: I B Tauris. 
Weaver, W. (1980), The Mathematical Manuscripts of Charles Lutwidge Dodgson (Lewis Carroll) in the Morris L. Parrish collection, microfilm, Princeton: Princeton University Library.

Wilson, R. (2008), Lewis Carroll in Numberland: His Fantastical Mathematical Logical Life, London: Allen Lane.

Zurlini, F. (2004), 'The library of the physician Romolo Spezioli (Fermo 1642 - Rome 1723): An example of the history of medical libraries,' Intellectual News, vol. 14, no. 1, pp. 34-43. https://doi.org/10.1080/17496977.2004.11417767

Amirouche Moktefi is lecturer in Philosophy at Tallinn University of Technology, Estonia. He is member of the Ragnar Nurkse Department of Innovation and Governance. He holds a PhD in the History and Philosophy of Science at the University of Strasbourg (2007). His research interests include the history of symbolic logic, visual reasoning and the philosophy of mathematical practice. 